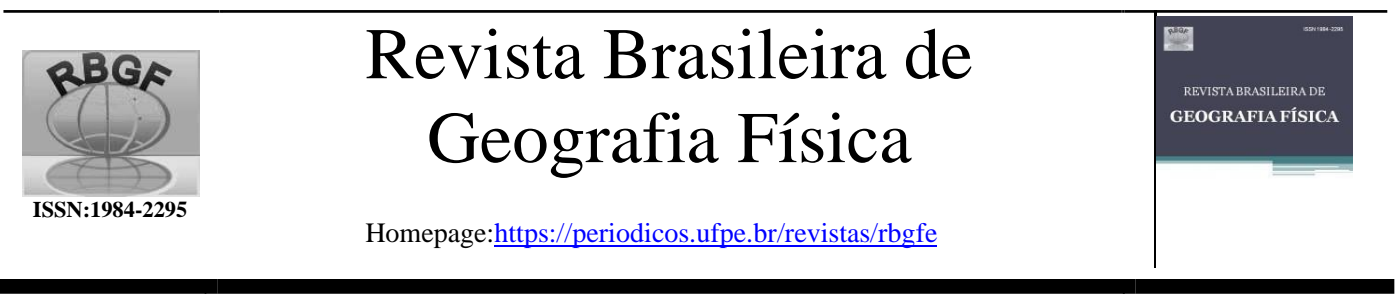

\title{
Analysis of Moisture Transport from Amazonia to Southeastern Brazil During the Austral Summer
}

\author{
Murilo da Costa Ruv Lemes ${ }^{1}$, Gilvan Sampaio de Oliveira², Gilberto Fisch ${ }^{3}$, Renata \\ Gonçalves Tedeschi ${ }^{4}$, João Pedro Rodrigues da Silva ${ }^{5}$
}

\begin{abstract}
${ }^{1} \mathrm{PhD}$ Student, CCST - Earth System Science Center, INPE - National Institute for Space Research, Astronautas Avenue, 1758 - São José dos Campos SP - Brazil - CEP 12227-010. (12) 991939099. murilo.ruv@ gmail.com. ORCID: https://orcid.org/00000003-2991-7755 (autor correspondente). ${ }^{2} \mathrm{PhD}$, Center for Weather Forecasting and Climate Studies (CPTEC) National Institute for Space Research (INPE) President Dutra Highway - 12630-000 Cachoeira Paulista - Sp Brazil ORCID: https://orcid.org/0000-0001-6956-3950. ${ }^{3}$ PhD University of Taubaté (UNITAU) Municipal Road Professor Dr. José Luís Cembraneli, 5000 - Sandra Maria Garden, Taubaté - SP, 12081-010. ORCID: ORCID: https://orcid.org/0000-0001-6668-9988.

${ }^{4}$ Center for Weather Forecasting and Climate Studies (CPTEC) National Institute for Space Research (INPE) and Vale Technological Institute (ITV) Street Boaventura da Silva, 955 Nazaré, Belém - PA, 66055-090, rgtedeschi@ gmail.com ORCID: https://orcid.org/0000-0002-9312-0030. ${ }^{5}$ Mastering, University of São Paulo Institute of Astronomy, Geophysics and Atmospheric Sciences (IAG). Street Matão, 1226, CEP 05508-900, Cidade Universitária, SP, Brazil. (12)991749905. joao.rod@usp.br ORCID: https://orcid.org/0000-0001-9619-7861
\end{abstract}

Artigo submetido em 03-06-2020 e aceite em 30-11-2020

\section{A B S T R A C T}

In two recent Austral summers (between the years 2013/14 and 2014/15), a southeastern region of Brazil suffered a period of severe drought. The main convective activity during the summer (mainly responsible for the rain) is an interconnected band of cloudiness with NW / SE orientation, which extends from the adjacent Atlantic Ocean to the SW of the Amazon, being called the South Atlantic Convergence Zone (SACZ). In addition to the SACZ, the passage of frontal systems also affects the rainfall distribution as well as some moisture oceanic input from the Atlantic Subtropical High pressure. Thus, the main objective of this work is to compute the moisture transfer from the Amazon region to the south and southeast of Brazil and associate it with the precipitation pattern. In addition, the influence of different types of El Niño Southern Oscillation (ENSO) in the moisture flow, for instance, Central (higher temperatures in the central equatorial Pacific) and East (higher temperatures in the eastern equatorial Pacific) were also studied. The summer of 2013/14 was the driest of the series (1979 - 2016). Although it was below the climatology, the precipitation trend found for the period is not significant, according Mann-Kendall test. However, it is clearly notable the importance of the moisture transport from the Amazon region to the southeast in neutral years, providing huge accumulated rainfall. Moreover, it is possible to affirm that there is a such significant difference in the intensity of the moisture flow in neutral years. Although, this intensity can be influenced by the position of the greatest anomaly of the sea surface temperature (ASST) in the Pacific. In other words, if this anomaly is greater in the eastern portion of the ocean (named as East El Niño Leste) an intensification in the flow is identified which will produce a greater amount of moisture in the regions. However, if the ASST is greater in the central region (El Niño Central), this intensification is lower, which may result in changes in the volume of precipitation in the region.

Keywords: ENSO Brazil, Climate Change, GPCP, reanalysis 


\section{R E S U M O}

Em dois verões austral recentes (entre os anos de 2013/14 e 2014/15), a região sudeste do Brasil sofreu um período de forte seca. No entanto, considerando que a principal atividade convectiva durante o verão (responsável pela chuva) é a faixa interconectada de nebulosidade com orientação NW / SE que se estende desde o Oceano Atlântico adjacente até à Amazônia SW, sendo denominada Zona de Convergência do Atlântico Sul (ZCAS). Além da ZCAS, a passagem dos sistemas frontais também influência a dinâmica e a precipitação na região. Durante o verão austral, em média, cinco frentes frias passam pela região e, associadas ao transporte de umidade proveniente da Amazônia, causam grandes volumes de chuva durante um determinado período ( 5 a 7 dias, dependendo de sua intensidade). Portanto, o principal objetivo deste trabalho é calcular a transferência de umidade da região amazônica para o sul e sudeste do Brasil e associá-la às chuvas. Além disso, observar a influência de diferentes tipos de classificação do El Niño Oscilação Sul (ENSO) no transporte de umidade, por exemplo, Central (temperaturas mais altas no Pacífico equatorial central) e Leste (temperaturas mais altas no Pacífico equatorial leste) foram estudados. O verão de 2013/14 foi o mais seco de toda a série analisado (1979-2016), embora abaixo de sua climatologia, não foi encontrada significância na tendência da série, após o teste de Mann-Kendall Contudo, é notável a importância da umidade oriunda da região amazônica para o sudeste em anos neutros. É possível afirmar que há uma diferença significativa na intensidade do fluxo de umidade, da Amazônia para o sudeste, em anos de ENOS. Embora, essa intensidade é indicada pela posição de maior anomalia da temperatura da superfície do mar (ATSM) no Pacífico. Em outras palavras, se essa anomalia é maior na porção leste do oceano (El Niño Leste) identifica-se uma intensificação no fluxo (maior quantidade de umidade nas regiões), porém, se a ATSM é maior na porção central (El Niño Central) a intensificação é menor, podendo resultar em modificações no volume das precipitações na região.

Palavras-Chave: ENSO Brasil, Mudanças Climáticas, GPCP, reanálises

\section{Introduction}

The austral summers of 2013/14 and 2014/15 were marked by extreme drought events, especially in the southeast region of Brazil. These events were reflected directly in the society as water rationing occurred in many cities in the state of São Paulo due to the lower levels or lack of water in the reservoirs. This was probably caused by a global atmospheric scale phenomenon which originated a very strong system of high pressure in the central part of Brazil acting as an atmospheric blockade, thus preventing formation of rain convective clouds and the passage of frontal systems (Coelho et al., 2015). Fontão et al. (2018) also analyzed this case using the spatial synoptic classification and rhythmic analysis technique and demonstrated that the input of air masses coming from the south was very low for these summers compared with the typical years. For instance, the accumulated annual rainfall in the entire of Sao Paulo state was 1,216 $\mathrm{mm}$ for 2013/14, and the rainfall during the austral summer was just $400 \mathrm{~mm}$, showing a negative anomalous wet period in relation to both the annual total and wet period climatological normal $(1,450 \mathrm{~mm}$ and $543 \mathrm{~mm}$, respectively) according to INMET (2019), and very close to the minimum total rainfall $(1,216 \mathrm{~mm})$ observed ( Liebmann et al. ,2002).

One of the most important large scale atmospheric phenomena in South America is the transport of moisture (Yang and Dominguez, 2019; Arias et al., 2019) from the Amazon rainforest region to the south and southeast of Brazil (Marengo et al., 2004, Vera et al., 2006, Weng et al., 2018), which is a process carried out by the general circulation of the atmosphere with oceanic and continental influences responsible for the distribution of rainfall throughout the continent (Arraut et al., 2012). Pena et al. (2020) has studied this moisture transfer to the southeast Brazil considering past and future scenarios. The authors have concluded that this moisture

\footnotetext{
Lemes, M. C. R., Oliveira, G. S., Fisch, G., Tedeschi, R. G., Silva, J. P. R.
} 
transfer can be higher for the future (that means more convergence at southeastern region). This study has used RCPs scenarios and high resolutions projections from CMIP5 models (the outputs were produced by HELIX Project (Helix, 2017)).

In addition to this transport, the Atlantic Subtropical High-Pressure Center (ASHPC), displaced to the center of the South Atlantic Ocean contributes to advect the moisture of the Atlantic Ocean to the continent, favoring the rainfall over the summer (Reboita et al., 2010). The moisture process has several coupled mechanisms, and one of the most important of them is the South Atlantic Convergence Zone (SACZ). This phenomenon was studied by Herdies et al. (2002), who observed an intense low-level jet (LLJ) transporting tropical moisture from the Amazon to the subtropics, generating convergence of the moisture flow and precipitation. In a different approach, Gastmans and Santos (2019) analyzed rainfall in the state of São Paulo using water isotopes and also demonstrated this Amazonian moisture transport. Also, Ramos et al. (2019) showed that this moisture transport can cross the Atlantic Ocean and reach southern Africa, thus confirming its importance for the water cycle of regions of the South Hemisphere Continents. The SACZ is the atmospheric system responsible for large volumes of rain in the austral summer which occurs during the months of December, January and February (DJF). During this season, the zone of maximum cloud coverage, precipitation and mass convergence is located in the north of São Paulo and the south of Minas Gerais states. The daytime convection is also observed in the Sao Paulo region and is considered an important mechanism for heavy rains. (Reboita et al., 2010; Rao et al., 2016).

Moreover, Lovejoy and Nobre (2018) showed a crucial connection of the global scale weather to deforestation in Amazon. These authors studied the negative synergies between deforestation, climate change, and widespread use of fire and they indicated a tipping point for the Amazon system to flip to non-forest ecosystems in eastern, southern and central Amazonia at a threshold of $20-25 \%$ of total deforestation of the forest. Therefore, this is a real problem for other Brazilian regions (the Southeast for example) because the climate (especially the moisture transfer and rainfall) will be impacted, and this will have negative effects on the economy of the region. In this context, it is important to emphasize that the Southeastern region represents $55.5 \%$ of the Gross Domestic Product (GDP) of the country, according Brazilian Institute of Geography and Statistics (IBGE) (ibge.gov.br/explica/ pib.php).

In addition, another phenomenon of oceanic / atmospheric interaction that affects this area in South America is the El Niño Southern Oscillation (ENSO). At a global scale, the El Niño occurs due to the abnormal heating of the surface waters of the Equatorial Pacific Ocean, thus causing teleconnection changes, especially in South America, in terms of precipitation and consequently in temperature. In Brazil the El Niño causes significant effects in different parts of the country, causing an increase in precipitation in the south (due to the increase in the intensity of the jet stream blocking the intrusions of air masses) and a decrease of rainfall in the southeast of Brazil, as it prevents the advance of cold fronts, which also contribute to rainfall. Also, during ENSO's events, precipitation decreases in the northeast and part of the north region (eastern and central Amazonia), modifying the intensity of the local water cycle. Recently, Sori et al. (2019) divided the amazonian moisture transfer between 2 different watersheds (Negro river and 
Madeira) and associated their characteristics with ENSO events and its influence on the Southeast region of Brazil.

Tedeschi et al (2015) observed a connection between the increase in frequency and persistence of El Niño events with extreme precipitation events. Using the methodology El Niño Central (CEN - similar to the 3.4 region) and East (EEN - similar to the 3 region), they also identified variations in some meteorological parameters (e.g. precipitation, omega vertical velocity, vertical integrated moisture flow and others). Recently, Cai et al. (2020) did a detailed analysis of the impact of ENSO on precipitation over the entire south America.

The main objectives of this study were to investigate the transport of moisture from the Amazon to the Southeast region, analyzing its possible effect on the rainfall distribution in São Paulo state. Moreover, it was also shown the occurrence of different classifications of ENSO states (CEN and EEN) and their relationship with anomalies of moisture transport and rainfall. The hypothesis to be checked is that moisture transfer is an essential part of the water cycle in the São Paulo state.

\section{Data and Methods \\ Main Area}

For analysis of moisture transport, the period of data considered was 19792016. The regions were chosen according to the following criteria: for the Amazon Forest region, the objective was to analyze its Brazilian portion; for São Paulo state, the focus was on the hydrographic basin regions and, also, large dams which has the function of supply population and local energy generation as shown in Figure 1.

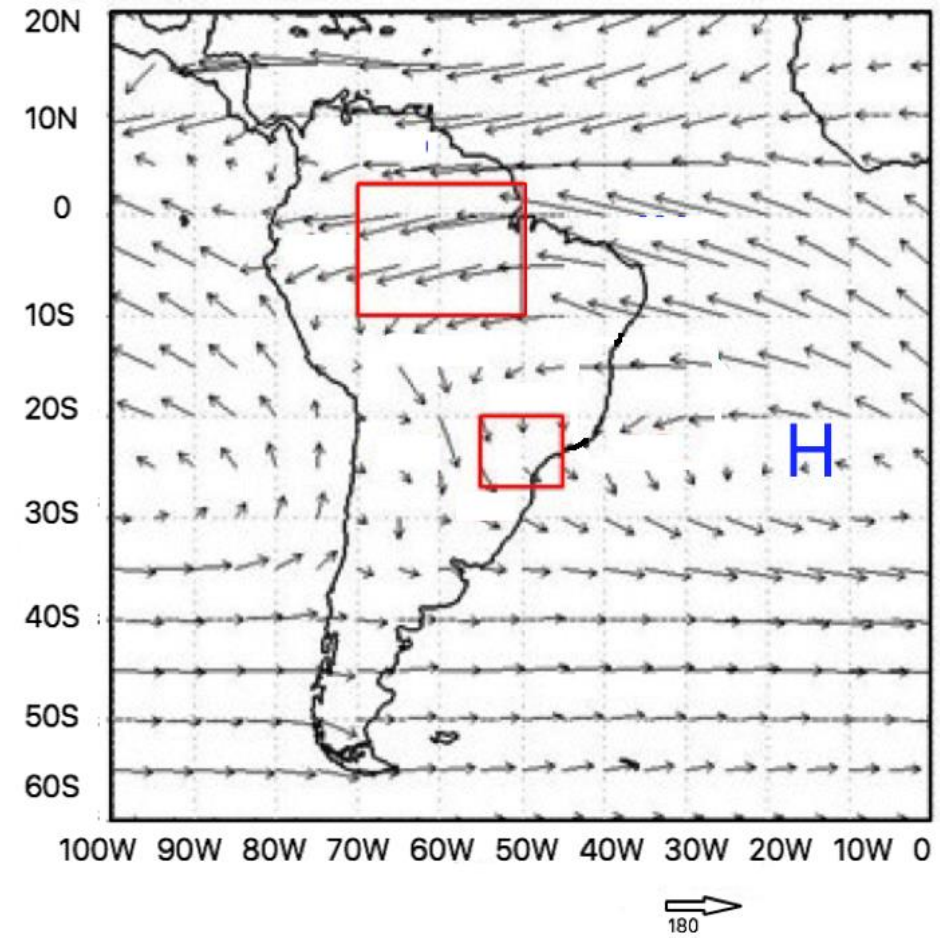

Figure 1 - The red squares indicate the areas where the moisture balance is calculated. The square next to the Equatorial line indicates the Amazon rainforest, the one located near the $20^{\circ}$ the São Paulo region. Finally, the letter $\mathrm{H}$ means the High-Pressure System over the Atlantic Ocean. 


\section{Datasets}

All data related to precipitation and the moisture computation transport (pressure, winds components and specific humidity) were obtained from the Global Precipitation Climatology Prediction (GPCP) (esrl.noaa.gov/psd

/data/gridded/data.gpcp.html) and NCEP/NCAR website reanalysis (ersl.noaa.gov/psd/data/gridded.data.ncep. reanalysis2), respectively. Basically, the GPCP dataset is a database that mixes various estimates of the atmospheric moisture from different sources and observations to produce fields of global precipitation.

Thus, the grid analysis is based on conventional and satellite observations measurements to calibrate the database.

\section{Analysis \\ Precipitation}

Initially, the distribution of annual rainfall in the regions of the Amazon rainforest and São Paulo state were calculated to better understand all the atmospheric mechanisms that act on typical and anomalous conditions in these regions. Therefore, it was observed how, in the anomalous period in question $(2013 / 14)$, the precipitation behaved in comparison with the climatology, following values by Coelho et al. (2015).

After a simple rainfall analysis, a series of maps of moisture transport in Brazil were elaborated on seasonal and annual time scales, considering some anomalous years that were observed in climatological analysis as 1988 (-negative deviation), 1995 (+positive deviation), 2004 (-negative deviation), 2014 (negative deviation).

\section{Vertically Integrated Moisture Flow}

Several calculations were performed using the dataset, such as monthly and annual averages, summation, anomalies, and composites, among other operations. The integrated vertical moisture flow (from the surface up to a level of $500 \mathrm{hPa}$ ) was calculated to analyze its behavior on a temporal scale, highlighting extreme years, that is, years with heavy rain and high transport of moisture and years with little rain and with a low intensity of transport. This integrated flow is calculated by the following equations:

$$
\begin{aligned}
& Q u=\frac{1}{g} \int_{p t}^{p o} q u d p \\
& Q v=\frac{1}{g} \int_{p t}^{p o} q u d v
\end{aligned}
$$

Where Qu (1) and Qv (2) represent moisture transport by the zonal (u) and meridional components of the wind $(\mathrm{v}), \mathrm{g}$ is the acceleration due to gravity, $\mathrm{q}$ is specific humidity, pt represents the pressure in the upper part of the integration domain (500h $\mathrm{Pa}$ ) and $\mathrm{Po}$ is the surface pressure.

The flow of moisture at the boundaries of the square is calculated by the components already presented in equations 1 and 2 . After defining the zonal and meridional components, the atmosphere is integrated up to $500 \mathrm{hPa}$. This level was chosen because it is the last one where the amount of moisture was considered expressive. The calculation is performed for each one of the limits of the square (east, west, north and south).

In order to calculate the flows, it is necessary to set boundaries, that is, latitude or longitude in each of the edges according to equations 3 and 4 .

$$
Q j=\frac{1}{g} \int_{\text {lat } 1}^{l a t 0} Q i d x
$$

$$
Q k=\frac{1}{g} \int_{l a t 1}^{l a t 0} Q i d y
$$


The $\mathrm{j}$ index (3) defines longitudes to be fixed as east or west boundaries. The lat1 (lat0) represents the latitude value at the south (north) edge. The $\mathrm{k}$ index (4) defines latitudes to set as north or south boundaries, lon1 (lon0) is the value longitude on the west (east) edge. The index in the equations represents the calculation of the vertically integrated moisture flow calculated by equations 1 and 2. In addition, the calculation of this equation represents the amount of moisture that remained in the respect area.

$$
\mathrm{C}=\mathrm{N}_{\text {fluxo }}+\mathrm{S}_{\text {fluxo }}+\mathrm{E}_{\text {fluxo }}+\mathrm{W}_{\text {fluxo }}
$$

The total calculation of the vertically integrated moisture balance $(C)$ over the Amazon and São Paulo is done by adding all the values of the boundaries of the domain used according to an equation 5. The positive (negative) values of $\mathrm{C}$ represent convergence (divergence) and consider that the region is a sink (source) of atmospheric moisture.

\section{Others Analysis}

The anomalies were computed as $\mathrm{X}^{\prime}=\mathrm{X}-(\underline{X})$, where $\mathrm{X}^{\prime}=$ anomaly, $\mathrm{X}_{\mathrm{i}}=$ observed in a specific year and $(\underline{X})=$ climatological average; positive and negative periods were identified throughout the period of study. The compositional method was also used in many of the maps produced, especially those that analyze the ENSO events. The technique of composition consists of the sum of a measurement over a period, which in this case the months of December, January and February were used, which correspond to the austral summer and part of the wet period. This period was used to represent a more stable and representative data analysis time frame.

The flows were calculated for specific years (rainier, drier, years of
ENSO, etc.) according to the rainfall climatology and GPCP (which describes the ENSO status). Finally, using a similar methodology, the anomalies of this transport were calculated according to the following equation (6), where $\mathrm{u}$ is zonal component of the wind and $\mathrm{v}$ is the meridional component:

$$
\sqrt{u * u+v * v}
$$

The significance test of the temporal tendency was made by Mann Kendall Test (MK). This test is usually utilized for analysis of temporal variation of a geophysical series and was described by Salviano et al. (2016). The $\mathrm{S}$ index is a statistical variable that is represented by (7) and can be computed as:

$$
S=\sum_{i=1}^{n-1}, \sum_{j=i+1}^{n} \operatorname{sgn}(x j-x i)
$$

The areas representing the Amazon forest area (red box) varies from the latitudes of $10^{\circ} \mathrm{S}$ up to $3^{\circ} \mathrm{N}$ and longitude $50^{\circ} \mathrm{W}$ up to $70^{\circ} \mathrm{W}$ and the area of São Paulo in the latitudes of $20^{\circ} \mathrm{S}$ up to $27^{\circ} \mathrm{S}$ and longitude $45^{\circ} \mathrm{W}$ up to $55^{\circ} \mathrm{W}$.

\section{El Niño Analysis}

For the present study, the methodology of Tedeschi et al (2015) was chosen for the classification of the phenomenon El Niño. For that, it is necessary to observe the temperature anomaly of the sea surface, that is, where the greatest anomaly is registered, El Niño will be characterized as Central (3) or East (3.4 or still referenced as Modoki).

The main objective of using this methodology is to point out the effects of El Niño and portions of the warm water on Pacific on the atmospheric flow over South America and, thus, influence the moisture

\footnotetext{
Lemes, M. C. R., Oliveira, G. S., Fisch, G., Tedeschi, R. G., Silva, J. P. R.
} 
transfer. During the last decades there have been evidence of an increase in the persistence of El Niño type events (Tedeschi et al., 2015).

\section{Results and discussion}

The time series of austral summer rainfall in São Paulo, collected from accumulated values of GPCP dataset is shown in Figure 2, and this figure shows if there is a pattern in rainfall volumes during the summer and any tendencies of precipitation for increase or decrease. The orange line in Figure 2 indicates a tendency of reduction of precipitation in São Paulo during the period studied, while the red continuous line indicates the climatological average (in the amount of $530 \mathrm{~mm}$ ) of the period. In the Amazon (data not shown but presented in Ruv Lemes et al., 2017), the average precipitation is $670 \mathrm{~mm}$ and the time series

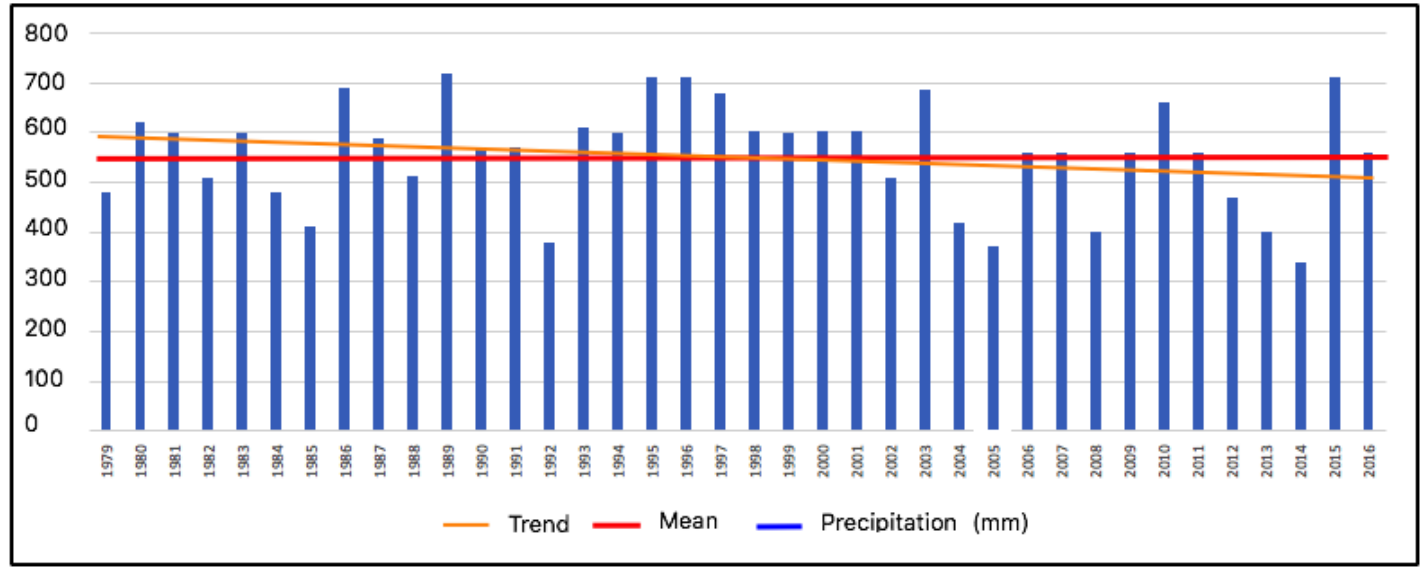

Figure 2 - Time series of precipitation $(\mathrm{mm})$ in the quarter DJF in São Paulo.

Figure 3 shows the mean integrated vertical moisture flow pattern during the austral summer, between the surface and $500 \mathrm{hPa}$, and the box represents the area of moisture transport calculation. For calculation of these numbers, only the typical years were considered (the years of ENSO were excluded) for the estimates. The entry of moisture in the Amazon occurs at the east showed a negative trend, with 16 years below average, 4 years at average and 18 years above average. However, in the summer 2013-2014, the volume of rainfall in the southeast region showed a systematic reduction, being mostly below the climatological average line. Although it showed a decreasing tendency line, the results did not show a statistically significant (Mann-Kendall Test).

This is also the case for the year 1982/83 (ENOS) which registered a total rainfall far below the average $(560 \mathrm{~mm})$. It is known that the pre-rainy season (SON) of that year was also marked by a low precipitation accumulation (Veiga et al., 2017) and there was a generalized drought across the Amazon region (Borma and Nobre, 2013). 
at the west and south edges. Subsequently, much of the moisture input in the region of São Paulo is represented by positive values (in blue) on the north and west edges which come from the Amazon. It is known (Arraut and Nobre, 2012) that a considerable amount of precipitation in this region occurs associated with this transport. There is an increase in this contribution in years of ENSO, with changes in atmospheric circulation and a higher intensity of the jet stream moisture flow when compared to the climatological average, as will be discussed later. In addition, it is necessary to say that the moisture that arrives in the southeast region has some contribution from the ASHPC, which has not been estimated during this work.

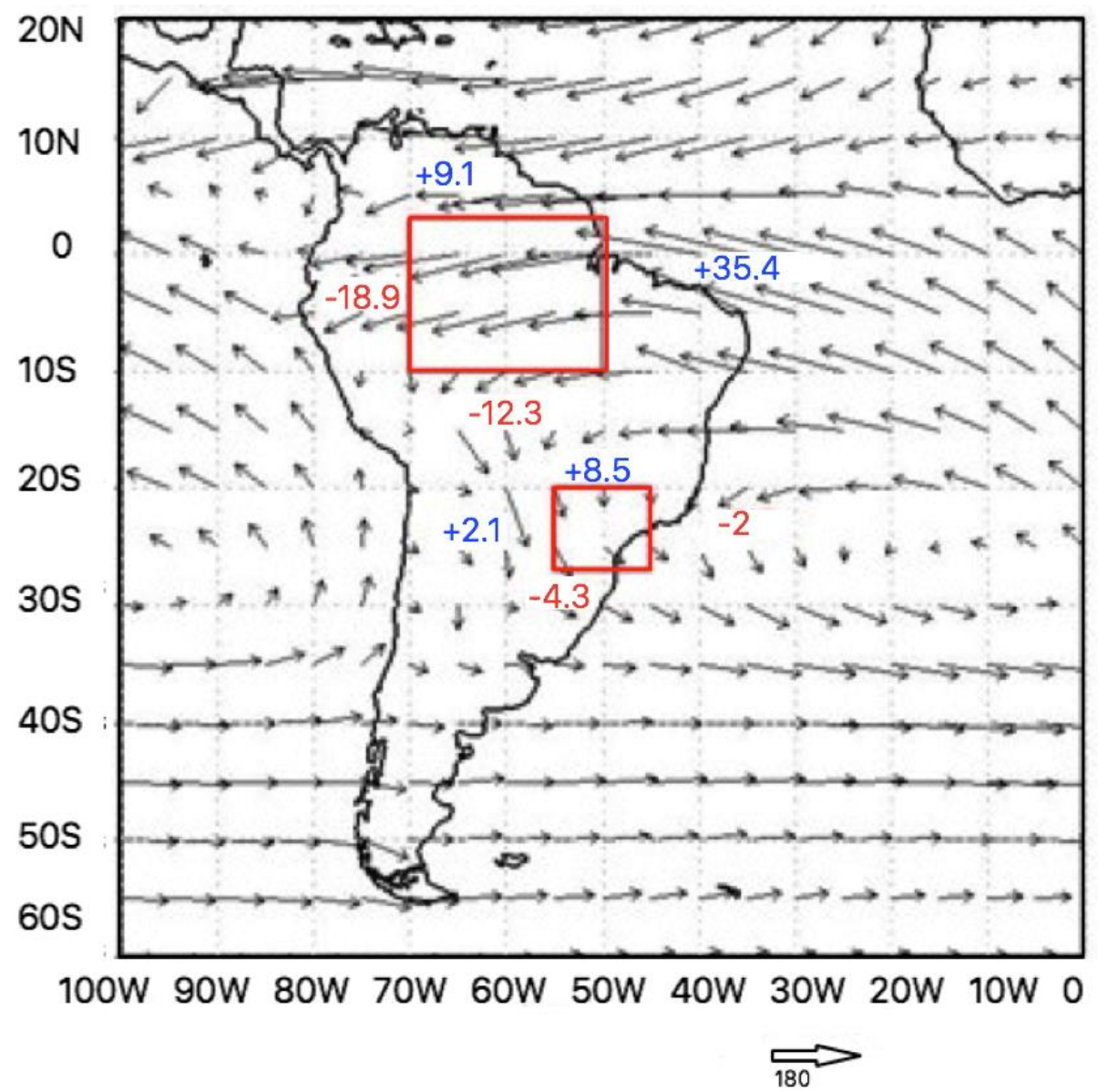

Figure 3 - Mean of the Integrated Vertical Moisture Flow ( $\mathrm{kg} / \mathrm{s})$ of the entire study period (1979 - 2016), excluding years of ENSO.

To better understand the behavior of moisture transport, the anomaly of the amount of moisture remaining in the region was calculated, in other words, the year in question subtracted the climatology (climatological values of each boundaries of the square). Table 1 shows the moisture anomalies that occurred in the Amazon and São Paulo regions during the period from 1979 to 2016, that is, the amount of precipitation that remained in the areas. In 2011, the region of São Paulo had a large decrease in the amount of moisture that remained, consistent with the precipitation

Lemes, M. C. R., Oliveira, G. S., Fisch, G., Tedeschi, R. G., Silva, J. P. R. 
data, which indicated a reduction in this same period (Figure 3). On the other hand, the Amazon presents a greater amount of moisture from the years 2000 with Table 1 - Time series of the anomaly of the amount of moisture $(\mathrm{kg} / \mathrm{s})$ that remained in São Paulo and Amazonia.

\begin{tabular}{|c|c|c|}
\hline YEAR & SÃO PAULO & $\begin{array}{l}\text { AMAZON } \\
\text { REGION }\end{array}$ \\
\hline 1979 & +1.2 & -6.1 \\
\hline 1980 & +3.3 & -6.2 \\
\hline 1981 & +3.4 & -5.2 \\
\hline 1982 & +0.6 & -8.9 \\
\hline 1983 & -2.1 & -3.4 \\
\hline 1984 & -2.3 & -2.8 \\
\hline 1985 & +0.6 & -0.4 \\
\hline 1986 & -1.0 & -1.4 \\
\hline 1987 & -2.3 & -1.7 \\
\hline 1988 & +0.7 & +4.0 \\
\hline 1989 & -1.4 & -1.7 \\
\hline 1990 & +1.2 & +2.0 \\
\hline 1991 & -3.8 & -6.0 \\
\hline 1992 & -2.5 & +2.0 \\
\hline 1993 & -1.5 & +2.4 \\
\hline 1994 & +3.4 & -0.2 \\
\hline 1995 & +0.7 & -2.0 \\
\hline 1996 & +3.2 & -1.5 \\
\hline 1997 & +3.2 & -5.3 \\
\hline 1998 & -0.9 & +2.3 \\
\hline 1999 & -2.3 & +3.0 \\
\hline 2000 & -0.4 & +4.5 \\
\hline 2001 & +0.2 & -0.5 \\
\hline 2002 & +1.2 & -1.0 \\
\hline 2003 & +0.9 & +4.7 \\
\hline 2004 & +2.4 & +4.0 \\
\hline 2005 & +2.0 & +8.9 \\
\hline 2006 & +4.3 & -2.1 \\
\hline 2007 & +3.2 & +7.2 \\
\hline 2008 & -2.3 & +7.1 \\
\hline 2009 & +2.3 & +1.2 \\
\hline 2010 & +0.2 & +5.9 \\
\hline 2011 & -2.3 & +6.5 \\
\hline 2012 & -2.3 & -0.7 \\
\hline 2013 & -2.4 & -1.7 \\
\hline 2014 & -2.5 & -2.0 \\
\hline 2015 & -2.7 & +0.2 \\
\hline 2016 & +10.0 & +8.0 \\
\hline
\end{tabular}

following years below the average: 2002, 2006, 2012, 2013 and 2014. 
Figure 4 indicates the moisture flow in the DJF quarter during the year of greatest rainfall in the Amazon forest region (1988), and also in the year of less rainfall (2014). The moisture that remained in 1988 in the Amazon region was $21.5 \mathrm{~kg}$ / s, while in 2014 this quantity was reduced to $16.4 \mathrm{~kg} / \mathrm{s}$ of moisture, a reduction of $23.8 \%$ associated with water vapor transport.
Such a decline is noticeable on the eastern border of the Amazon (Figure 4), with a decrease of $3 \mathrm{~kg} \mathrm{/} \mathrm{s}$ and, proportionally, a decrease in moisture output, especially at the western edge of that box. This also was proven by Fontão et al. (2018), which studied two different dry years in Sao Paulo amongst them 2014.

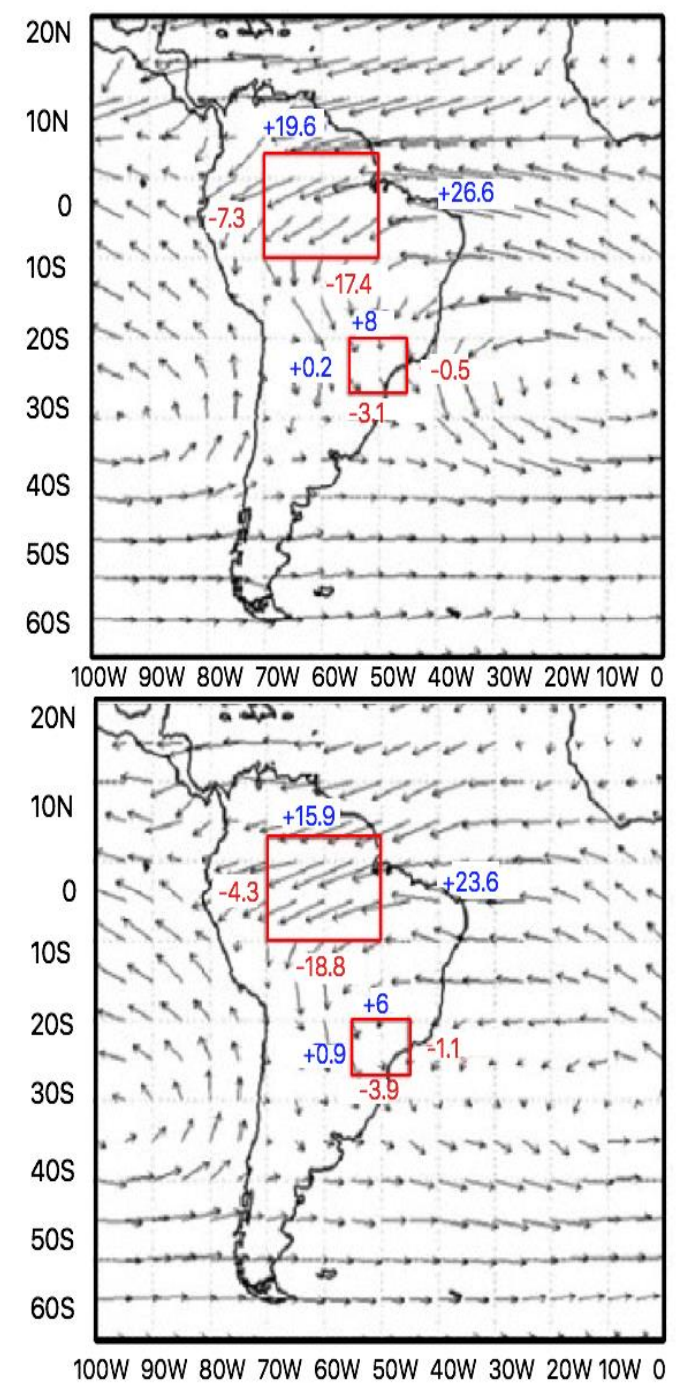

$\underset{180}{\Rightarrow}$

Figure 4 - Mean of the Integrated Vertical Moisture Flow of the 1988 DJF (wetter year) and 2014 (drier year) quarter in the Amazon.

The integrated vertical moisture flow, shown in Figure 5, was computed 
for the DJF quarter for two extreme years in São Paulo: 1995 which was chosen as the wettest year, and 2014 during the drought, with the aim of showing how moisture transport is spatially distributed in these years. The atmospheric moisture that arrived in São Paulo in 1995 (13.7 kg / s) is almost double of the value observed in $2014(6.9 \mathrm{~kg} / \mathrm{s})$, demonstrating a very large deficit of moisture, which comes mainly from the Amazon region (north face of the box). It is also evident that from 2007 to 2009 there is a stagnation of rainfall values, and from the year 2010 up to 2016 the trend line is below the average (Figure 2).

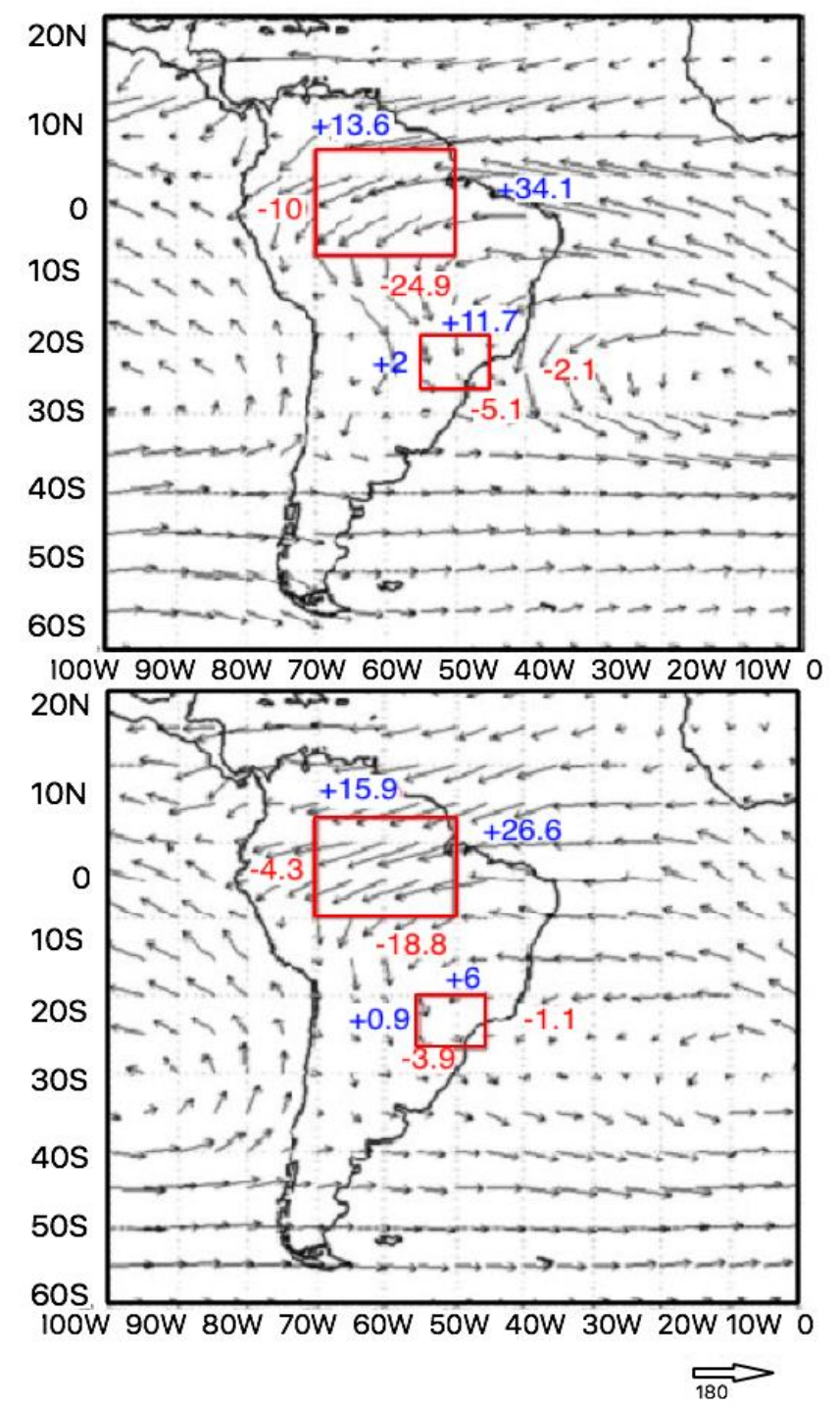

Figure 5 - Mean of the Integrated Vertical Moisture Flow of the DJF quarter of 1995-1996 (wetter year) and 2014-2015 (drier year) in São Paulo.

As was previously described, the ENSO modifies the rainfall distribution in Amazonia and then its transport to the
Southeast region. Therefore, Figure 6 illustrates the moisture flux composite only considering years of East El Niño events

Lemes, M. C. R., Oliveira, G. S., Fisch, G., Tedeschi, R. G., Silva, J. P. R. 
(1982/83, 1986/87, 1991/92, 1997/98) following Tedeschi et al. (2015) classification. It is possible to compare the fluxes with Figure 3, since the intensity of the vertical integrated flow of moisture is greater when this phenomenon is present (around $30 \mathrm{~kg} / \mathrm{s}$ of exit flow), whereas the average value of the climatological value is around $27.5 \mathrm{~kg} / \mathrm{s}$. In only 4 years with ENSOs (El Niño) events, a low number when compared to neutral years (25), its mean identifies an increase of intensity of this flow of moisture, which is not necessarily accompanied by rain, but rather by an increase in the transport of that moisture.

In the state of São Paulo, this same intensification of the moisture transport in the region was identified, with an increase for ENSO years $(1982 / 83,1986 / 87$, 1991/92, 1997/98). However, the quantity of moisture that left the territory remained constant, so that a convergence of moisture occurred in the areas demarcated on the map by the box.

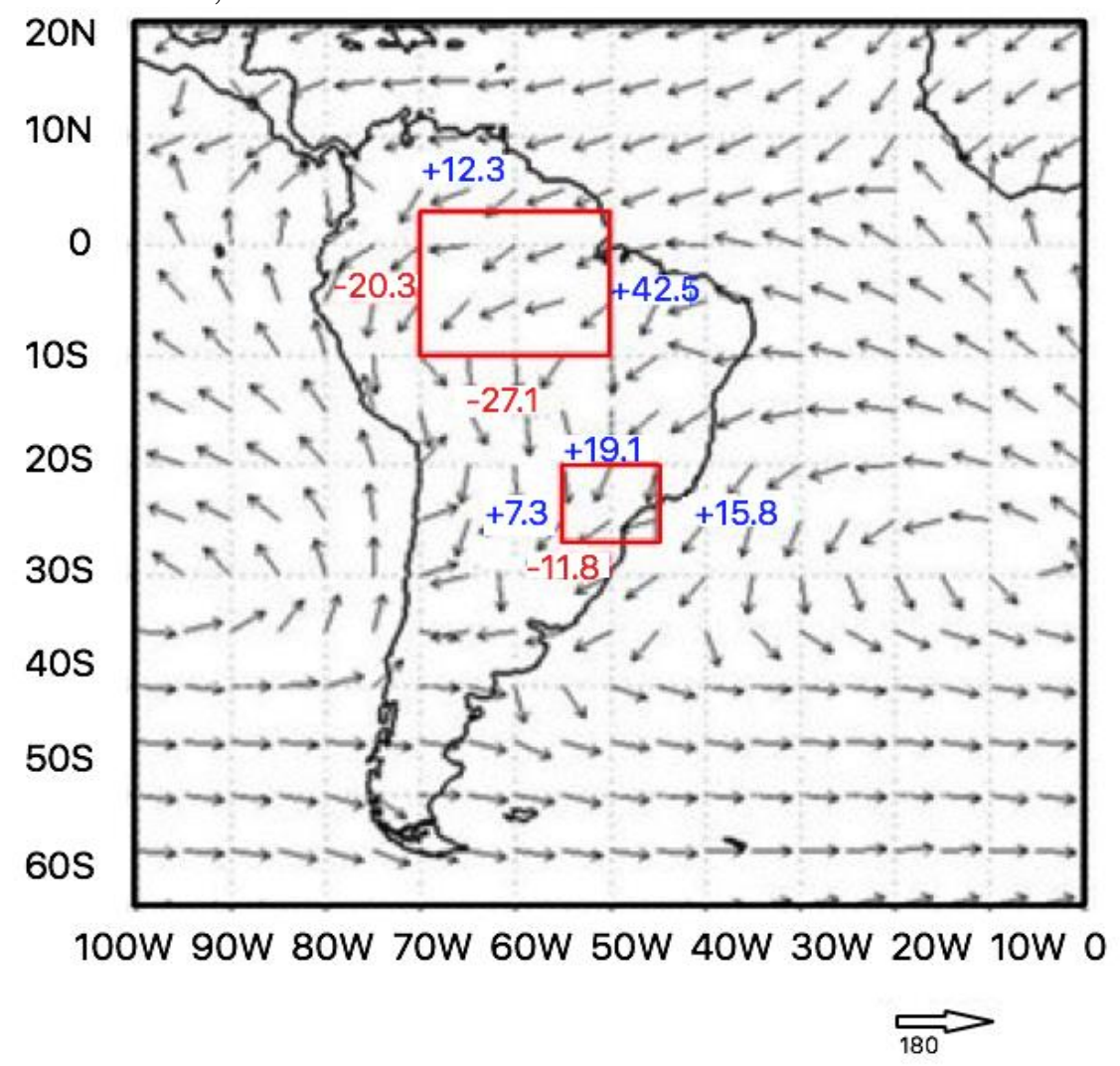

Figure 6 - Vertical Integrated Moisture Flow Composition of the DJF quarter for years with an El Niño event (1982/83, 1986/87, 1991/92, 1997/98).

Tedeschi et al. (2015) investigated the ENOS events and its impact in the rainfall at Sao Paulo region and proposed that analysis in two segments (El Niño Central-CEN and El Niño East-EEN) can better represent its influence on Brazil.
Therefore, the analyses shown in Figure 6 were recomputed by considering the CEN and EEN events (Figure 7). In this way it was possible to calculate the relation of moisture transport, especially of the rainfall regime in São Paulo. In the case of EEN, the intensity of the inflow of moisture is higher than in the CEN, but the 
outputs are similar. Therefore, the moisture convergence for the EEN case is greater than for CEN. In the case of the São Paulo region, the accumulation of moisture during a EEN case is very large $(\Delta \mathrm{Q}=30.4$ $\mathrm{kg} / \mathrm{s}$ ) in comparison with the case of CEN (convergence of $9.4 \mathrm{~kg} / \mathrm{s}$ ).

Using the same methodology, we have separated the different types of ENSO, considering the integrated vertical flow and jet stream, as well as a possible precipitation dipole between the South and Southeast regions of Brazil in CEN years. There are differences in its effects for the different types of ENSO (EEN and CEN) according to Ruv Lemes et al. (2017), so it is possible to explain the anomaly calculation shown in Figure 8, which shows the magnitude of the jet stream $(250 \mathrm{hPa})$ located in South America and intensified in El Niño years. However, this figure shows that there is a difference in the jet stream pattern for the different types of El Niño. In the case of the EEN (1997) the jet stream has great intensity and is located, even without great positive deviations, up to the Atlantic Ocean. In the case of CEN (2004), the jet stream's intensity is different, especially over the southeast of Brazil, with negative numbers, thus indicating a lower intensity of the winds. The anomaly of the jet stream for 2004 - a CEN year, in vectors, showed an opposite direction (from east to west) in the jet stream, thus explaining the decrease in intensity, different from what is seen in 1997 (EEN year), in which the flow (from west to east) is located between Uruguay and southern Brazil with a much higher intensity when compared to each other. It is well known (Tedeschi et al., 2015) that the EEN produces a very strong jet current and yet this intensity does not cause any effect on the precipitation volumes in the state of São Paulo, in particular. Figure 8 shows the integrated vertical moisture flow of 1997, a year marked by a strong EEN. During this year, DJF presented a smaller number of cold fronts in the southeast region (Boletim Climanálise, 2014), but this did not affect the precipitation volume (669 mm). This can be explained by the fact that there is a compensation of the transport of moisture from the Amazon region to São Paulo state, that is, the moisture that comes from the Amazon region is higher than in a neutral period. In addition, intense rainfall events increased in those years, as seen in Tedeschi et al. (2015), which showed an increase in the presence of these events when compared to neutral years. In Figure 3, the moisture convergence at the north border of São Paulo for a neutral period is positive (+) 7.1 $\mathrm{kg} / \mathrm{s}$ of moisture. 

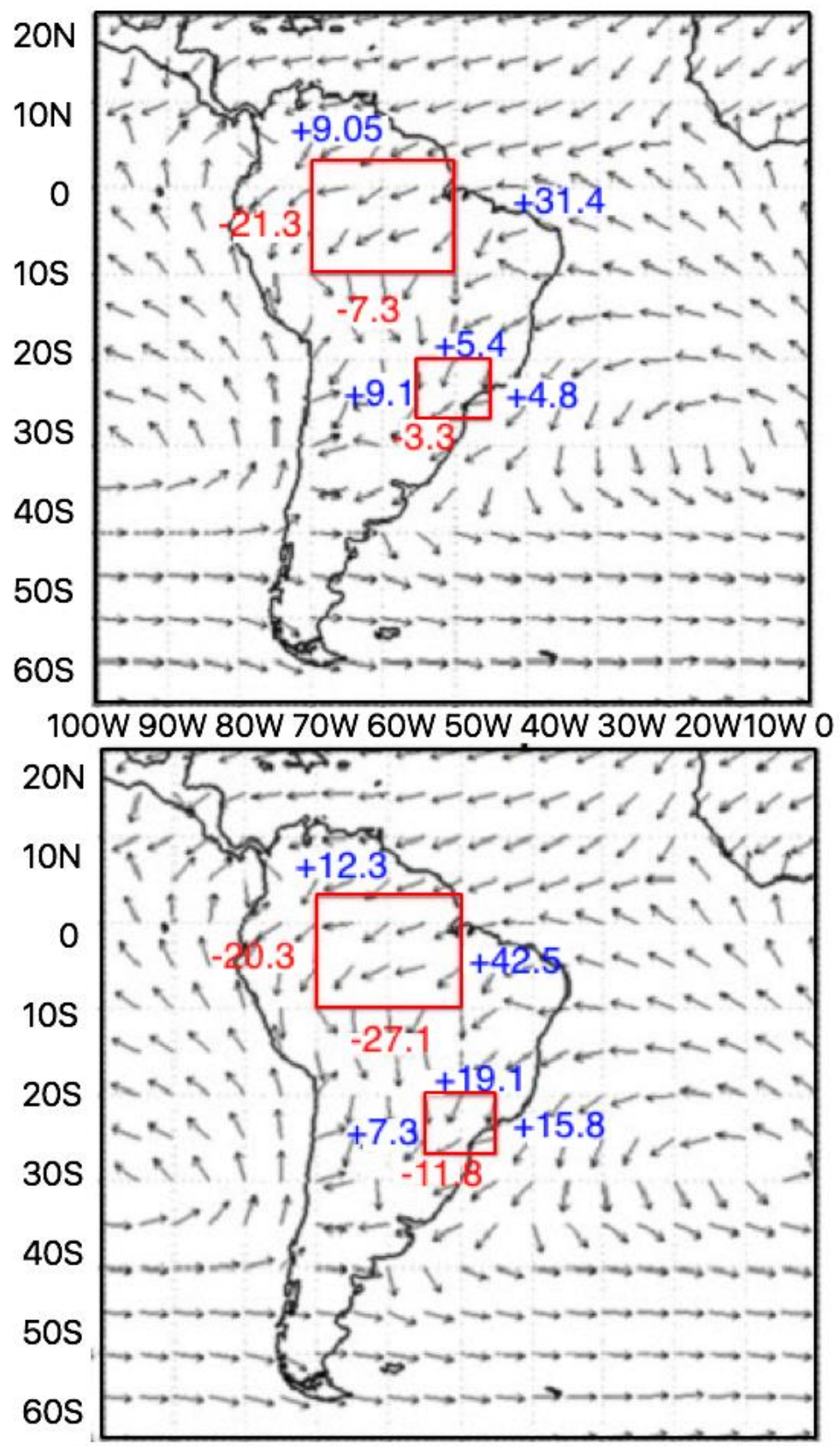

100W 90W 80W 70W 60W 50W 40W 30W 20W10W 0

\section{$\stackrel{\longrightarrow}{\longrightarrow}$}

Figure 7 - Composites during years of El Nino Central (1990, 1994, 2004) and East (1982, 1986, 1991, 1997) during the summer DJF.

Lemes, M. C. R., Oliveira, G. S., Fisch, G., Tedeschi, R. G., Silva, J. P. R. 


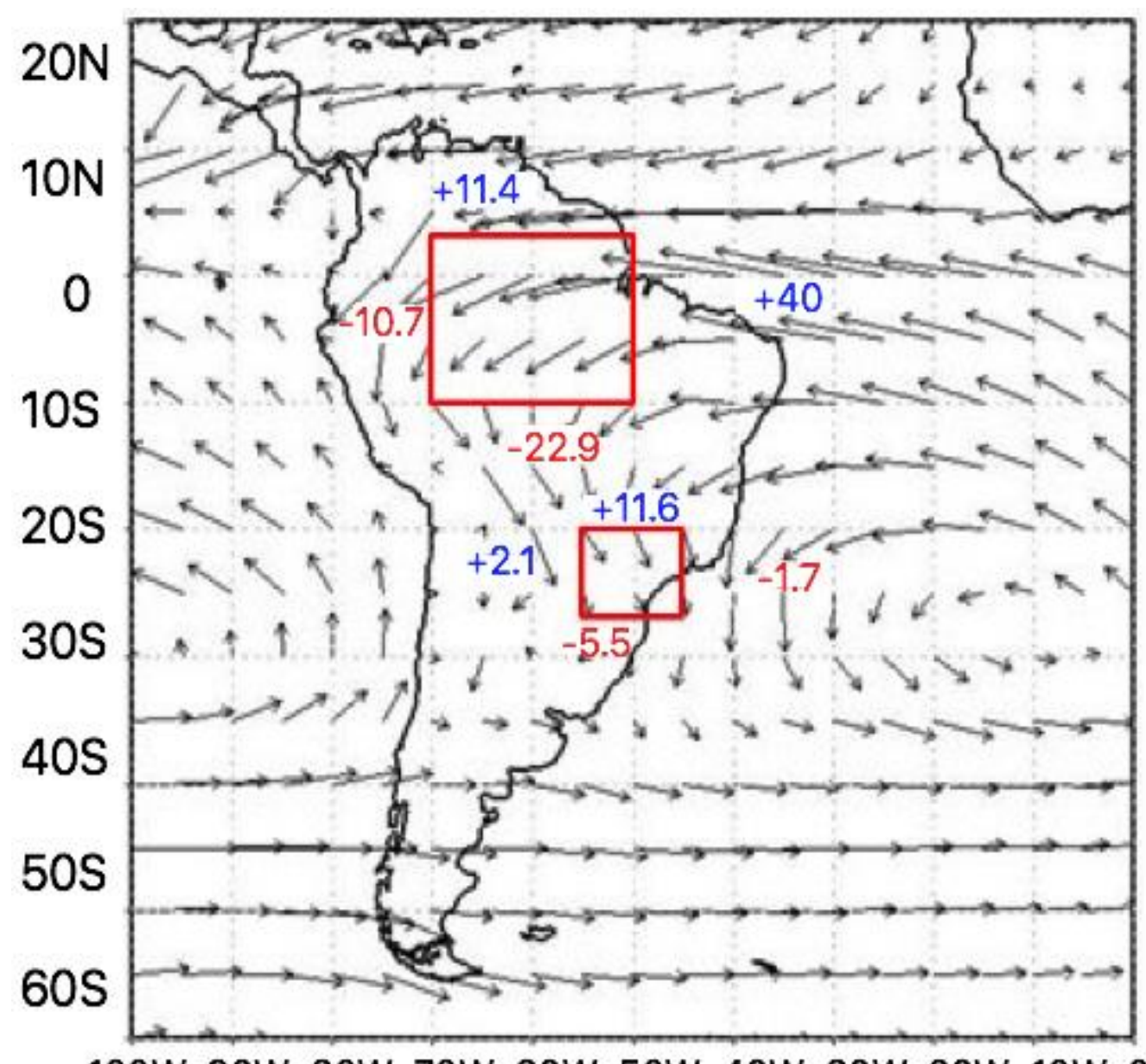

100W 90W 80W 70W 60W 50W 40W 30W 20W 10W 0

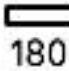

Figure 8 - Mean of the integrated vertical moisture flow of 1997 - year with presence of EEN.

Table 2 is based on the occurrence of Frontal Systems (FS) in the São Paulo region. In the years of EEN, such as 1997 , the cold fronts suffered a blockage due to the upper jet stream, and in years of CEN (Marengo et al., 2004), as its intensity decreases, the FS can more easily move northward. In 1997, considered to be an EEN year, 9 FS events were registered in São Paulo, $64.2 \%$ below the climatological average (14 frontal systems). In contrast, in 2004 (CEN), 14 FS events were recorded, and this value was equal to the climatological average, indicating the difference of effect of the position and intensity of the jet stream for different types of ENSO. In 1988, another significant year since there was a La Niña event, there were 21 FS events (50\% above the average for the period) that arrived in São Paulo state during the austral summer, with January being the month with the highest precipitation (twice its normal climatological value). 
Table 2 - Frontal System Occurrence in the São Paulo region represented by years of ENSO events and by the neutral years (1982-2019).

Cold Fronts in the São Paulo region

\begin{tabular}{ccccc}
\hline Year & December & January & February & Total \\
\hline$(1982-2019)$ & 5.5 & 4.9 & 5.4 & 15.8 \\
\hline 2015 & 8 & 10 & 2 & 20 \\
\hline 2004 & 4 & 5 & 5 & 14 \\
\hline 1998 & 7 & 8 & 6 & 21 \\
\hline 1997 & 2 & 3 & 4 & 9 \\
\hline 1983 & 5 & 7 & 5 & 17 \\
\hline 1982 & 1 & 4 & 3 & 8 \\
\hline
\end{tabular}

After a summer with reduced values in the moisture balance in São Paulo (as can be seen in Table 3), the summer of 2015-2016 was marked by the recovery of the level of water reservoirs in the state of São Paulo (Coelho et al., 2015). Considering the vertical integrated moisture flow, it is possible to relate this increase in the amount of precipitation and events of intense rainfall to the moisture coming from the Amazon rainforest at the western edge of the box. In neutral years this edge has an average of $1.8 \mathrm{~kg} / \mathrm{s}$ of moisture, while for this summer, there were $12 \mathrm{~kg} / \mathrm{s}$ of moisture (Table 3), which contributed to the increase of rainfall amounts in the Southeast region.

Table 3 - Moisture Transport in the summer of 2013/2014.

\begin{tabular}{ccc}
\hline Edges & Amazon & São Paulo \\
\hline North & +15.9 & 6.0 \\
\hline South & -18.8 & -3.9 \\
\hline East & +23.6 & -1.1 \\
\hline West & -4.3 & +0.9 \\
\hline Moisture Transport in the austral summer of $2015 / 2016$ \\
\hline Edges & Amazon & São Paulo \\
\hline North & +7.6 & 10 \\
\hline South & -23.5 & -6.9 \\
\hline East & +39.4 & -5.8 \\
\hline West & -19.3 & +12.3 \\
\hline
\end{tabular}

The Amazon region, on the other hand, presented a greater stability in terms of intensity and the distribution of moisture during the period, with few periods of

Lemes, M. C. R., Oliveira, G. S., Fisch, G., Tedeschi, R. G., Silva, J. P. R. 
drought (years of 2003, 2009 and 20142015). These results are very important for understanding the role that the Amazon region transfers moisture to other parts of South America as well as the necessity for protection of the Amazon region.

\section{Summary and Conclusion}

The transport of moisture from the Amazon to the southeast of Brazil is of extreme importance, being partly responsible for the rainfall regime in São Paulo during the austral summer (DJF). In neutral years, the moisture transport from the Amazon region had an average of about $17.6 \mathrm{~kg} / \mathrm{s}$ that remained, and in São Paulo this value was $1.9 \mathrm{~kg} / \mathrm{s}$. During ENSO years, this contribution of the transport of moisture from the Amazon is even more important, due to the intensified upper jet stream $(250 \mathrm{hPa})$. It was also

shown that there are differences between the two types of ENSO: for CEN cases, there was lower moisture transport from the Amazon, and the opposite occurred during EEN years. In particular the austral summer 2014/2015 (an EEN event), the intensity of the integrated vertical moisture flow was below the expected value for the period $(44.1 \%)$.

\section{References}

Arias, P. A., Ruiz Vasquez, M., Martinez, J. A., Vieira, S. C., Meija, J. D., Pazos, M. J., Agudelo, J., Espinoza, J. C. 2019. The Andes-Amazon connection: pathway of atmospheric moisture transport. American Geophysical Union, Fall Meeting. 1, A24K - 03.

Arraut, J. M.; Obregon, G.; Barbosa, H.; Marengo, J.; Nobre, C. 2012. Aerial Rivers and Lakers: Looking at LargeScale Moisture Transport and Its Relation to Amazon and to Subtropical Rainfall in South America. Journal of Climate 25, 1, 543 - 556,. Available: 10.1175/2011 JCLI4189.1.
Borma, L. D. S., Nobre, C. A. 2013. Secas na Amazônia causas e consequências. São Paulo: Oficina de Textos 367 p.

Cai, W., McPhaden, M. J., Grimm, A. M., Rodrigues, R. R., Taschetto, A. S., Garreaud, R. D., Dewitte, B., Poveda, G., Ham, Y., Santoso, A., Ng, B., Anderson, W., Wang, G., Gend, T., Jo, S. J., Marengo, J. A., Alves, L. M., Osman, M., Li, S., Wu, L., Karamperidou, C., Takahashi, K., Vera, C. 2020. Climate impacts of the El Niño-Southern Oscillation on South America. Nature 1, 215-231.

Carvalho, L. M. V., Jones, C., Liebmann, B. 2002. Extreme Precipitation Events in Southeastern South America and Large-Scale Convective Patterns in the South Atlantic Convergence Zone. Journal of Climate 20, 15, 2377 - 2394.

Coelho, C. A. S., Cardoso, D. H. F., Firpo, M. A. F., 2015. Precipitation diagnostics of an exceptionally dry event. Theoretical Applied Climatology 16. Available: 10.1007/s00704-0151540-9.

Dewitte, B., Cuervo, J. V., Goubanova, K., Illig, S., Takahashi, K., Cambon, G., Purca, S., Correa, D., Gutierrez, D., Sifeddine, A., Ortlieb, L., 2012. Change In El Niño flavours over 1958-2008: implications for the long-term trend of the upwelling off Peru. Deep-Sea Res. II Top. Stud. Oceanog 2, 143-156. Available: 10.1016/j.dsr.2.2012.04.011.

Fontão, P. A. B., Zavattini, J.A., Sheridan, S.C., Armond, N. B., 2018. Gênese das chuvas em São Paulo (SP): Estudo Comparativo entre a "Spatial Synoptic Classification" e a "Análise rítmica em climatologia". Revista Brasileira de Climatologia, v. 23.

Gastmans, D., Santos, V., 2018. O papel da Amazônia no regime de chuvas no Sudeste. Unesp Ciência 104, 1-5. 
HELIX. High-End cLimate Impacts and eXtremes. 2017. Met Office and Exeter University. Available: Project 603864.

Herdies, D. L., Dias, M. A. F. S., Ferreira, R. N., 2002. The moisture budget of the bimodal pattern of the summer circulation over South America. Journal of Geophysical Research 107, 42-4 4210. Available: 10.1029/2001JD000997.

Horel, J. D., Hahmann, A. N., Geisler, J. E., 1989. An investigation of the annual cycle of convective activity over the tropical Americas. Journal of Climate 2, 11,1388 - 1403 .

IBGE. Instituto Brasileiro de Geografia e Estatística, 2020. Available in <https://www.ibge.gov.br/> Access in: july 27, 2020.

INMET. Instituto Nacional de Meteorologia, 2019. Available in < www.inmet.gov.br/portal $>$ Access in: 01 de agosto de 2019.

Lee, T., Mcphaden, M. J., 2010. Increasing intensity of El Niño in the centralequatorial Pacific. Geophys. Res. Lett 37 , 4603. Available:10.1029/2010GL044007.

Lovejoy, T., Nobre, C., 2018. Amazon Tipping Point. Science Advanced 4, 1 2. Available: $10.1126 /$ sciadv .aat 2340

Marengo J. A., Soares, W., Saulo, C., Nicolini, M., 2004. Climatology of the LLJ east of the Andes as derived from the NCEP reanalysis. Journal of Climate 17, 2261-2280.

Na, H., Jang, B. G., Choi, W. M., Kim, K. Y., 2011. Statistical simulations of the future 50-year statistics of cold-tongue El Niño and warm-pool El Niño.AsiaPac. Journal Atmosphere Science 47(3), 223-233. Available: 10.1007/s13143011-0011-1.

NOAA. National Oceanic and Atmospheric Administration, 2017. Available in < http:// www.esrl.noaa.gov/psd/data/gridded/d ata.gpcp.html >. Access in: August 29/2017.
Obregon, G. O., Marengo, J. A., Nobre, C. A., 2014. Rainfall and Climate Variability: long-term trends in the Metropolitan Area of São Paulo in the 20th century. Climate Research 61, 2, 93 - 107. Available: $10.335 / \mathrm{cr} 01241$.

Penna, A. C., Torres, R. R., Garcia, S. R., Marengo, J. A. 2020. Moisture flow on southeast Brazil: Present and future climate. International Journal of Climatology, doi: 10.10 02/ joc 6738.

Ramos, A. M., Blamey, R. C., Algarra, I., Nieto, R., Gimeno, L., Tome, R.; Reason, C. J. C., Trigo, R., 2019. From Amazonia to southern Africa: atmospheric moisture transport through low-level jets and atmospheric rivers. Ann. N.Y. Acad. Sci 1436, 217-230. Available: $10.1111 /$ nyas.13960)

Rao, V, B., Franchito, S, H., Santo, C, M, V., Gan, M., 2016. An update on the rainfall characteristics of Brazil: seasonal variations and trends in 19792011. International Journal of Climatology 26, 291 - 302. Available: 10.1002/joc.4345

Reboita, M. S., Gan, M. A., Ambrizzi, T., 2010. Regimes de precipitação na América do Sul: uma revisão bibliográfica. Revista Brasileira de Meteorologia 25, 185-204.

Ruv Lemes, M. C., Sampaio, G. O., Fisch, G., Tedeschi, R. G., 2017. Analysis of moisture transport from Amazonia to the Southern Brazil during austral summer. Chycle SCI Forum 1, 1 - 8.

Salviano, M. F., Groppo, J. D., Pellegrino, G. Q., 2016. Análise de tendência em dados de precipitação e temperatura no Brasil. Revista Brasileira de Meteorologia, 31, 1, 64-73.

Silva Dias, M. A. F., Dias J., Carvalho, L. M. V., Freitas, E. D., Silva Dias, P. L., 2012. Changes in extreme daily rainfall for São Paulo, Brazil. Climatic Change 116 (3-4), 705-722.

Sori, R., Marengo, J. A., Nieto, R., Drumond, A., Gimeno, L., 2018. The 
Atmospheric Branch of the Hydrological Cycle over the Negro and Madeira River Basins in the Amazon Region Water 10, 738. Available: DOI:10.3390/w10060738).

Tedeschi, R. G., Grimm, A. M., Cavalcanti, I. F. A., 2015. Influence of Central and East ENOS on extreme events of precipitation in South America during austral spring and summer. International Journal of Climatology, 1, 35, 2045 - 2064. Available: 10.1002/joc.4106.

Vera, C., Baez, J., Douglas, M., Emannuel, C., Marengo J. A., Meitin, J., Nicolini, M., Noguez Paegle, J., Paegle, J., Penalba, O., Salio, P., Saulo, S., Dias, M. S., Dias, P. S., Zipser, E ., 2006. The South American low-level jet field experiment. Bulletin of the American Meteorological Society 87, 63-77.

Yang, Z. Dominguez, F., 2019. Investigating Land Surface Effects on the Moisture Transport over South America with a Moisture Tagging Model. Journal of Climate 2, 66276644.

Yu, J. Y., Kim, S. T. I., 2013. Identifying the types of major El Niño since 1870. International Journal Climatology 33, 2105-2112.

Available: 10.1002/joc.3575.

\section{Attachments}

Thereunder (Table 4), we presented the annual precipitation data serie for each DJF (1979 - 2016).
Table 4 - Data series of accumulated precipitation for DJF (1979 - 2016). Following the colors: Neutral Years, Central El Niño, East El Niño and La Niña

\begin{tabular}{|c|c|}
\hline Year & Precipitation \\
\hline 1979 & 491 \\
\hline 1980 & 610 \\
\hline 1981 & 600 \\
\hline 1982 & 505 \\
\hline 1983 & 601 \\
\hline 1984 & 580 \\
\hline 1985 & 513 \\
\hline 1986 & 690 \\
\hline 1987 & 592 \\
\hline 1988 & 510 \\
\hline 1989 & 723 \\
\hline 1990 & 550 \\
\hline 1991 & 555 \\
\hline 1992 & 310 \\
\hline 1993 & 605 \\
\hline 1994 & 602 \\
\hline 1995 & 711 \\
\hline 1996 & 705 \\
\hline 1997 & 680 \\
\hline 1998 & 600 \\
\hline 1999 & 595 \\
\hline 2000 & 605 \\
\hline
\end{tabular}


Revista Brasileira de Geografia Física v.13, n.06 (2020) 2650-2670.

\begin{tabular}{|c|c|}
\hline Continuation & \\
\hline 2001 & 600 \\
\hline 2002 & 505 \\
\hline 2003 & 691 \\
\hline 2004 & 410 \\
\hline 2005 & 373 \\
\hline 2006 & 552 \\
\hline 2007 & 550 \\
\hline 2008 & 404 \\
\hline 2009 & 557 \\
\hline 2010 & 650 \\
\hline 2011 & 545 \\
\hline 2012 & 475 \\
\hline 2013 & 400 \\
\hline 2014 & 321 \\
\hline 2015 & 705 \\
\hline 2016 & 560 \\
\hline
\end{tabular}

